\title{
On crystallized oxide of chromium
}

\section{M.F. Wöhler}

To cite this article: M.F. Wöhler (1836) On crystallized oxide of chromium, Philosophical Magazine Series 3, 8:45, 175-175, DOI: 10.1080/14786443608648837

To link to this article: http://dx.doi.org/10.1080/14786443608648837

册 Published online: 01 Jun 2009.

Submit your article to this journal 중

Q View related articles $₫$ 
ON CRYSTALlIZED OXIDE OF CHROMIUM. BY M. F. WÖHLER.

When perchoride of chromium is passed in the state of vapour, through a glass tube heated to redness, it is decomposed into oxide of chromium, which remains in the tube in a crystalline form, and a mixture of chlorine and oxygen gases. The crystals of oxide of chromium thus obtained are black, of a metallic lustre, hard, well defined, and brilliant, possessing exactly the same form as the native peroxide of iron ( $f$ er oligiste), which confirms the isomorphism before recognised in these two oxides. The exterior characters of these oxides, when crystallized, are precisely similar; the specific gravity of this oxide of chromium is $5 \cdot 21$, nearly approaching to that of oxide of iron; but whilst the latter gives a red powder, that of the former is green, like the common oxide of chromium. These crytals are as hard as corundum, which, next to the diamond, ranks as the hardest known body.-Journal de Pharmacie, Juin 1835.

\section{NEW SCIENTIFIC BOOKS.}

A Manual of Britisn Vertebrate Animals. By the Rev. Leonard Jenyns, M.A., F.L.S., \&c.

An Elementary Treatise on the Computation of Eclipses and Occultations. By J.W. Lubbock, Esq., F.R.S., \&c.

Notices of Communications to the British Association for the Advancement of Science; at Dublin, in August 1835.

Geology of Yorkshire, Vol. II. By Prof. Phillips.

Philosophical Transactions, Part II. 1835.

Remarks occasioned by Lord Brougham's Paley's Natural Theology illustrated. By Thomas Martin.

\section{METEOROLOGICAL OBSERVATIONS FOR DECEMBER 1835.}

\section{REMARKS.}

Chiswick-December 1. Clear and fine : cloudy and windy at night. 2. Very fine. 3. Cloudy, 4, 5. Fine. 6. Frosty and foggy. 7. Foggy. 8. Hazy : rain. 9. Cloudy and cold. 10. Slight snow. 11-13. Sharp frost. 14, 15. Hazy. 16, 17. Dense fog. 18. Clear : hail shower at noon. 19. Cloudy and cold. 20. Slight snow. 21. Overcast : clear and cold. 22. Sharp frost : foggy. 23-26. Frosty and foggy. 27. Cloudy. 28. Fine. 29. Overcast. 30. Fine. 31. Frosty with dense fog. The quantity of rain in this month amounted only to a quarter of an inch.

P.S. Observing the discrepancy apparent in your last Journal between the results of cbservations at the Apartments of the Royal Society and at this Garden, I intended to have sent some account of the instruments used here, and their situation. Such will be necessary; but as some investigations are being made on the subject, I thought it better to defer it till next Number. I shall therefore only remark that the thermometers here, indicating the max. and min. of temperature, are in an open space, unaffected by radiation from buildings-a circumstance which must have a very great influence on those used for the same purposes at Somerset House.R. Thompson.

Boston.-December 1, 2. Fine. 3. Cloudy, 4, 5. Fine. 6. Cloudy. 7, 8. Foggy. 9. Cloudy: rain early A.M. 10 11. Fine. 12. Cloudy. 13. Fine. 14, 15. Cloudy. 16. Fine. 17. Foggy. 18. Fine. 19. Snow: stormy night with snow. 20,21. Cloudy. 22-26. Fine. 27-30. Cloudy. 31. Fine. 